\title{
Just Security and the Crisis of Global Governance
}

\section{William Durch, Joris Larik and Richard Ponzio}

Humanity lives and operates simultaneously in three spaces critical to contemporary life and governance: public, transactional and ecological. Failures in one space can cascade into others. Managing them so as to avoid such failures is an essential function of global governance.

Public space is the home of governance (formal and informal) and of rights-exercising groups and individuals enjoying areas maintained for common use. Civil society fully exercising its basic human rights is essential to a well-functioning state, and well-functioning states are critical supporting elements in the present architecture of global governance. Wherever states are fragile or torn by conflict, they become fracture points in that architecture. Transactional space - the realm of trade, finance, and other markets and networks, especially digital - has experienced explosive growth in the last two decades. The new global economy is marked by openness and low costs of communication and transport but also greater vulnerability to, and opportunity for, transnational crime. Both of these spaces depend, in turn,

\footnotetext{
William Durch is a Distinguished Fellow at the Stimson Center in Washington DC and served as Research Director for the Commission on Global Security, Justice \& Governance. Joris Larik is Assistant Professor of Comparative, European and International Law at Leiden University, and a Senior Researcher at The Hague Institute for Global Justice. He served on the core project team for the Commission on Global Security, Justice \& Governance. Richard Ponzio is Director of Just Security 2020: Advancing the Recommendations of the Commission on Global Security, Justice \& Governance at the Stimson Center. Previously, as Head of the Global Governance Program at The Hague Institute for Global Justice, he served as Project Director for the commission. This article is partially adapted from 'Confronting the Crisis of Global Governance', the report of the Commission on Global Security, Justice \& Governance co-chaired by former US secretary of state Madeleine Albright and former Nigerian foreign minister Ibrahim Gambari. The authors' companion edited volume to the commission's report, Just Security in an Undergoverned World, will be published by Oxford University Press in 2017.
} 
on ecological space, the planet-wide system of systems that influence one another and set the background conditions for human life and civilisation.

In none of these spaces are current tools and institutions of global governance up to the challenges they face. Mass violence in fragile states, cross-border economic shocks and cyber attacks, and the threat of runaway climate change threaten the public, transactional and ecological spaces of human existence. Getting global-governance reform right, however, will require paying close attention to the provision not just of security, but also of justice - and seeing to it that the two are mutually reinforcing.

\section{Just security}

Whereas security has always been considered integral to global governance, and to the mission of the United Nations, global justice has not been accorded similar central importance. Yet of the four main aims identified in the preamble to the 1945 UN Charter, only one - 'to save succeeding generations from the scourge of war' - is primarily security-focused. The preamble makes it clear that keeping war at bay is a means to other, even greater ends: human rights and dignity, gender equality, social and economic progress, liberty and justice.

Before the UN Charter, the pursuit of security was enshrined in the Covenant of the League of Nations, and, before that, at least in one part of the world, in the Concert of Europe. The notion of justice emerged more resolutely in deliberations at the global level with the charter, a result of the insight that to truly defeat the scourge of war, collective or common security alone is not enough. Unless both security and justice are guaranteed reflecting humanity's yearning not only to survive but to thrive with dignity - neither security nor justice is sustainable over the medium to long term. Security is merely the appearance of order, in a framework of structural violence, unless it is tempered or leavened by concepts of justice that include human rights, human dignity and other normative limits on the use of power. The pursuit of justice, in turn, is crippled if it is not backed up by the requisite means to maintain order. The intersection between security and justice, or 'just security', is an essential element of any global-governance enterprise or architecture. ${ }^{1}$ 
Security enhances justice by creating stable conditions - social, economic and political - for justice to take root and flourish; bringing greater urgency to justice goals, by stressing close links with immediate security concerns; and helping make advances in justice irreversible. Justice reinforces security by addressing many of the root causes of insecurity at different levels of governance (such as inequality, lack of transparency, corruption and authoritarianism); ${ }^{2}$ balancing the short-termism of many security imperatives with the medium- to long-term considerations of justice; and helping to expand the constituency for security promotion to a broader range of public- and private-sector actors.

Of course, security and justice also differ in several ways. Security promotion tends to be a status-quo-oriented endeavour, although the status quo a security institution aims to defend post-conflict and post-reform may be different than that which its predecessor institutions promoted. Once set in motion, however, security promotion tends to have considerable institutional momentum and affinity for functional stability. Institutions of justice can also be highly conservative - procedurally and politically - but justice promotion itself is more often viewed, at least by its supporters, as progressive and potentially transformational. It is therefore often contentious, and may be seen as a threat to social elites. Security-sector reform and postconflict peacebuilding can be seen as ways to make security and stability supportive of transformational aspects of justice.

Global-security imperatives (such as prosecuting the 'global war on terror' and removing the threat of nuclear, biological or chemical weapons) can undermine the promotion of justice at the local level - for example, when civilians are affected directly by economic sanctions and military actions. Justice and security are rarely considered equal in any given situation, such as when force protection takes precedence over building rule-of-law institutions because it is less risky for the intervening external actors. In cases where short-term trade-offs favour security and the promotion of stability, the goal should be to return to balance as quickly as possible, with justice - as embodied in military law codes, International Humanitarian Law, International Human Rights Law, and mission rules of engagement - positioned to serve as a constant governor of security and stabilisation actions. 


\section{Emerging global-governance actors}

As the United Nations enters its eighth decade, the world is less Westphalian than ever. Indeed, it is more appropriate to speak not of one, but of at least three United Nations, consisting of the member states, the secretariat and UN bureaucracy, and independent, yet UN-affiliated, civil-society organisations. ${ }^{3}$ These and other actors are assuming an increasingly prominent role within the wider global-governance architecture. They can serve both as contributors to and as detractors from security and justice. ${ }^{4}$

Firstly, international and regional intergovernmental organisations, both within and outside the UN system, feature prominently in global governance. Many regional and sub-regional organisations, such as the Association of Southeast Asian Nations (ASEAN), the African Union (AU), the Union of South American Nations (UNASUR) and the European Union (EU), are increasingly developing a global outlook and serve as partners to global multilateral efforts, including peace operations. For instance, the EU fights piracy off the coast of Somalia, ASEAN has become the driver of building a wider, ASEAN-Pacific governance architecture, and the AU undertakes 'hybrid' peace missions in cooperation with the UN.

Secondly, local authorities, cities and other sub-state actors, some of which are formally part of government, claim considerable powers in their jurisdictions, but they can also make distinctive contributions to global governance. Regions, municipalities, and mega- or global cities are increasingly regarded as new structures of decentralised decision-making that fit the speed and changing nature of the global economy. The world's 750 largest cities already account for $57 \%$ of global GDP. Local communities, for their part, are the first responders for climate-change adaptation or rebuilding efforts after conflict. ${ }^{5}$

Thirdly, civil society is represented by more than 4,0oo non-governmental organisations at the UN's Economic and Social Council, as well as by many other prominent organisations worldwide - such as Human Rights Watch, Amnesty International and Greenpeace. Global philanthropy, moreover, wields staggering amounts of wealth, in many cases surpassing official development assistance (ODA) from countries such as the Netherlands, the 
United Arab Emirates and Canada, which are among the top-ten state ODA contributors. ${ }^{6}$

Fourthly, the role of the business sector in global governance has long been acknowledged, and continues to grow. This sector includes multinationals: powerful, globally operating entities. The 2,ooo largest companies in 2014 accounted for $\$ 38$ trillion in revenues and employed 90 million people worldwide. ${ }^{7}$ This category also encompasses international media organisations and local entrepreneurs as important drivers of post-conflict recovery, as well as adapters to new technologies on the ground.

These developments notwithstanding, premature declarations of the demise of the state as a relevant entity in global governance should be resisted. Global governance by a plethora of diverse actors is not anarchy, but a world state as the singular provider of justice and security is not imminent, nor is any benevolent unipolar moment. The state remains the primary addressee of obligations under international law and other global norms. In particThe state remains the primary ular, it remains the primary provider of justice and security to its citizens and within its territory.

Concepts such as the Responsibility to Protect addressee of obligations under international law (R2P), the UN Guiding Principles on Business and Human Rights, and the Rome Statute of the International Criminal Court acknowledge, rather than refute, the continuing pre-eminent role of the state. An important part of $\mathrm{R}_{2} \mathrm{P}$ is affirming that the state remains primarily responsible for keeping its citizens safe. Despite (or because of) the growing power of the private sector, especially multinational corporations, states are called upon to ensure the protection of human rights on their territory. The Statute of the International Criminal Court, via the principle of complementarity enshrined in Articles 1 and 17, similarly stresses the state's primary responsibility for bringing perpetrators of atrocities to justice. Yet each of these key norms and documents make clear that where states fail to deliver, other levels and actors of governance need to step in. Hence, although states may continue to be seen as primarily responsible, they are not the only, nor necessarily the most suited, providers of justice and security; they may 
find themselves in need of assistance regarding the most serious threats and challenges in global governance.

The roles of international organisations and, in particular, subnational levels of government and a wide variety of commercial and civil-society actors, have long been recognised as critical to humanitarian and disaster relief and post-conflict reconstruction. More recently, the contributions of non-state actors in grappling with the challenges of climate change have been recognised as critical, for instance in the 2013 Lima-Paris Action Agenda. ${ }^{8}$ Governance of the internet, similarly, has always been a multistakeholder, multilevel enterprise with governments as collaborators, but not controlling partners, of a global network that is $90 \%$ privately owned.

\section{State fragility and political violence}

The problems of fragile states and their 'ungoverned' spaces (that is, areas under the control of private militias, terrorist groups or no one in particular) are not just domestic. ${ }^{9}$ They tend to cascade disorder into neighbouring states. They can be used as transit zones by drug or human traffickers and are prone to having their resources looted for international markets.

The World Bank Institute calculates that more than 1.5 billion people live in countries affected by fragility and conflict, and more than half of those people live in poverty, compared with $22 \%$ for all low-income countries taken together. Conflict-affected states are some of the least developed in the world. ${ }^{10}$

Since 2005, states have agreed in principle that they have a responsibility - inherent in the laws and norms that guide state behaviour, and in recognition of the dignity of the individual person - to prevent genocide, war crimes, ethnic cleansing and crimes against humanity within their borders, and that other states have a responsibility to extend protection against such crimes should a government fail to exercise that responsibility or itself become a perpetrator. These principles are consistent with sovereignty being understood more in terms of the responsibility of public authority toward those under its control than as the unbridled prerogative of those wielding power.

The corollaries of $\mathrm{R}_{2} \mathrm{P}$ are responsibilities to prevent and to rebuild. With regard to prevention and peacemaking, it is vitally important that states 
and institutions make greater efforts to bring women into conflict mediation, peace negotiations and processes of peace implementation, as they are better placed to address women's differential experiences of conflict and their concerns for and interests in rebuilding sustainable peace.

Over the past two decades, the United Nations, NATO, the European Union, the African Union and other regional organisations have undertaken peacekeeping and stabilisation operations (the latter where peace must be created and then kept). Most peacekeepers have deployed under the UN flag. In the vast majority of new operations over the past quarter-century, UN forces have faced one or more armed groups either not a party to major peace accords or otherwise inclined to use force against the UN. The need to keep upwards of 90,000 troops and 13,000 police in the field in eight complex operations for years at a time - rotating and replacing contingents on a regular basis every six to 12 months and coping with increasingly dangerous operating environments - has placed the UN's peacekeeping system under extraordinary stress. The comparable peak period in the 199os lasted less than three years, as did the average complex operation. ${ }^{11}$

Today's operations are more likely to last seven to ten years in equally unstable environments. ${ }^{12}$ Nor is it clear that demand has peaked. Thus far, no complex peacekeeping operation has ever deployed in the Middle East or North Africa (we count the seven-year US presence in Iraq as occupation and counter-insurgency, rather than peacekeeping). Yet Libya could hardly be worse off than it is today, riven and politically adrift, if international forces had been present from the start of NATO's operations there to provide impartial on-the-ground security and to encourage regional militias to return home and disband. Nor, given the tidal wave of refugees presently crashing against European shores, is it clear that denial of all but palliative care in regards to the Syrian civil war has brought about better results in terms of either security or justice than more resolute external support to forces opposing a regime clearly in egregious breach of its $\mathrm{R} 2 \mathrm{P}$ obligations, or at least much greater pressure on the regime itself.

Meanwhile, the United States and its European allies are weary of foreign interventions, after almost a decade of war in Iraq, and longer still in Afghanistan. But in the case of closer-by conflicts, what you do not care 
to visit will eventually visit you. And they will use GPS-enabled phones and downloadable maps to do so, after involuntarily contributing substantial amounts to the growing wealth of organised criminal traffickers, and losing family members in the process. The absence of positive support to peace preventive or corrective - means greater leeway for the forces of disorder.

To improve UN capacity to deploy well-trained troops and police in peace operations, the report of the Commission on Global Security, Justice \& Governance, 'Confronting the Crisis of Global Governance', recommended earmarking select member-state military units and formed police units for UN service on a rolling basis; doubling UN military-planning capacity; expanding the UN's standing capacity to deploy individual police officers and civilian experts by a factor of ten; and establishing a police and civilian reserve capacity able to staff up the management capacity of new operations in a matter of weeks rather than months. ${ }^{13}$ But the interests of the global community, neighbouring states and the country confronting its own crisis of governance could be better met were the international and regional community also better able to effect conflict-prevention measures, which means developing better early warning and understanding of conflict drivers. Post-conflict, the same pool of knowledge could contribute to rebuilding and, with luck, transforming the underlying causes of conflict to support sustainable peace.

War-torn societies need more than one kind of post-conflict justice. They need legal or retributive justice, acknowledgement of wrongdoing, socioeconomic justice (in the form of compensation for injury or loss) and political justice (meaning democratic accountability, as well as public policy and services). ${ }^{14}$ Peacebuilders should also be especially sensitive to the fact that building government legitimacy in the eyes of society requires anticorruption strategies built into capacity-building programmes, giving equal emphasis to personal and institutional integrity and ways to incentivise it. Reducing corruption is essential to building effective rule of law.

\section{Global financial and economic volatility}

When the 2008 financial crisis in the United States rippled quickly through the international financial system, the damage felt by many regional and 
national economies heightened a sense of both insecurity and injustice. The International Monetary Fund (IMF) estimated global bank losses due to the financial crisis as exceeding $\$ 4 \operatorname{trn},{ }^{15}$ contributing to a prolonged economic crisis in Europe that subsequently triggered political and constitutional crises. Meanwhile, in developing countries, falling prices and export demand, accompanied by reversals of capital flows and reductions in remittances, have resulted in declining output and employment. ${ }^{16}$ These shocks to the global economic system have threatened the very fabric of national economies, the often delicate social contract between governments and their citizens, and the personal and material security of individual citizens.

As the public discourse on Greece and the eurozone, and Thomas Piketty's popular work Capital in the Twenty-First Century on wealth distribution, both show, considerations of economic insecurity can quickly spill over into concern for key principles of justice, such as fairness, inequality and participation in governance. ${ }^{17}$ The International Labour Organisation (ILO) estimated that the global number of unemployed in 2009 was about $34 \mathrm{~m}$ higher than in $2007 \cdot{ }^{18}$ By 2013 , the global economy was still falling about $4 \mathrm{~m}$ jobs short of keeping pace with the growth in the labour force. ${ }^{19}$ Economic crises and inequality have worldwide spillover effects, as young people continue to face grim employment prospects. This has implications both for the scale of economic migration and for the potential attractiveness of extremist narratives offering place and purpose, however destructive, to those unable to find constructive alternatives. ${ }^{20}$

The risks of another global financial meltdown - amplified by poorly regulated markets for securities and currencies, as well as diverging interest rates and monetary policies in major economies - remains high. ${ }^{21}$ The 2008-09 crisis might not have triggered new trade and currency wars, but is today's global-governance architecture prepared to prevent future such scenarios? With the aim of adopting a just-security approach to managing global financial volatility and responding to future global economic shocks, new frameworks for global economic cooperation and crisis response should be developed, anchored by a reinforced G2o.

The G20 possesses several strengths, including the fact that it meets at the highest political level (at the Leaders Forum) since late 2008, and has a 
diverse, yet manageable number of members, accounting for two-thirds of the world's population, $85 \%$ of global GDP and over $75 \%$ of global trade. Yet the $\mathrm{G} 20$ has been only minimally institutionalised, with an annually rotating presidency and agenda, and no common staffing for purposes of continuity or linking up on a regular basis with other global or regional institutions.

A just-security approach would involve transforming the G2o into what might be called the 'G20+' (where the plus signifies new linkages, supported by a modest and possibly virtual secretariat) and strengthening its level of institutional coordination with the United Nations (including the General Assembly and the Economic and Social Council), the World Bank, IMF, ILO, World Trade Organisation and regional organisations. In brief, a G2O+ would promote integrated economic, social and environmental approaches to international problems and, in so doing, would build upon the G20's current interactions with civil society and the business community, as well as regional and sub-regional organisations, especially from regions underrepresented in the G20 itself: Central America, Andean South America, Africa, Southwest and Central Asia, and much of Southeast Asia. ${ }^{22}$

Secondly, the G2O+ would lend support to, and introduce financial and other incentives for, countries and regions that sustain financial and economic regulatory reform and renewal, while reducing economic nationalism. In support of these aims, it would promote transparency for all economic and financial actors and activities, as well as appropriate regulation and supervision. Finally, the $\mathrm{G}_{2} \mathrm{O}+$ would better respond to cross-border economic crises by leveraging far closer ties to the UN to enhance coordination (including technical and financial resources) between UN member states, global economic bodies, and regional and other development banks, including, as they gain experience, the Asian Infrastructure Investment Bank and the BRICS Development Bank.

To ensure greater institutionalised coordination between the G2O+ countries, the 193 UN member states, and representatives of major global and regional economic bodies, the $\mathrm{G} 2 \mathrm{O}+$ should meet at the heads-of-state level every two years at UN headquarters. In alternate years, the G2O+ would continue to meet in the country of a particular year's rotating president. Whereas the chief policy focus of the G2O+ should remain priority-setting 
on critical issues for the world economy, including in the area of crisis response, it should depend on formal international organisations and states for implementation and follow-through. To support the periodic meetings in New York and basic levels of coordination and exchange among the secretariats of global economic bodies, a light global economic-cooperation liaison mechanism should be created, involving senior staff from the G20+, the UN, and other major global and regional economic bodies. The justsecurity logic in this proposal holds that the G2O+ could and should focus on financial stabilisation and crisis avoidance, while working with its partners and through co-memberships to develop policies and strategies that aim to reduce economic inequality and build job opportunities. In turn, the broader aim would be to reverse the troubling global trend of decreasing confidence in governments.

\section{Climate change and human livelihoods}

The global climate is a priori beyond the reach of any single state to manage. There is no chance of a single state providing either justice (who pays?) or security (who suffers the consequences?) regarding climate change. Even if states were willing to act together, as the latest reporting from the science working group of the UN's Intergovernmental Panel on Climate Change (IPCC) argues is imperative, ${ }^{23}$ certain global processes seem already to have been set in motion that human action can no longer stop - such as the persistence of carbon dioxide in the atmosphere or the rising temperature and acidification of the open oceans. Dealing effectively with climate change may well require new understandings of what constitutes security, justice and governance in the twenty-first century.

Today we understand that collective human impact has become stronger as economies and populations have grown, and that it has global consequence. Current and projected human action is exerting a powerful influence on many planetary systems, including the atmosphere, oceans, fresh water and others. Each system has what scientists call 'planetary boundaries', safe operating conditions beyond which they may become unpredictable and even change state. Rebalancing their flows abruptly can have severely detrimental effects for humankind. ${ }^{24}$ 
Since the inaugural IPCC report in 1990, periodic updates have continued to deepen the scientific consensus around the nature, causes and effects of a changing global climate. In the IPCC's most recent assessment report, its fifth, the findings are most dramatic. Greenhouse-gas (GHG) levels are the highest they have been in more than 800,000 years, and rates of increase are the highest in 22,000. Global temperatures are predicted to rise more than $2^{\circ} \mathrm{C}$ above pre-industrial levels by 2100 unless global GHG emissions are pushed $40-70 \%$ lower by 2050 than they were in 2010, and fall to zero by $2100 . .^{25}$

Still, global institutions must do what they can to promote the mitigation of, as well as safe and effective adaptation to, climate change. Such efforts include energy re-sourcing and conservation, and plans to deal with larger storms, deeper

Geoengineering is a drastic yet

\section{appealing option} droughts, higher seas and attendant population displacements. Much is known and agreed about the science of climate change, its drivers and its likely regional variations. Much less is known or agreed about how to promote mitigation and adaptation on a broad enough scale as to make either approach effective yet affordable. Present global political institutions were designed neither to avoid nor to adapt their members' respective societies or economies to the effects of global climate change, with serious consequences for global security and justice if business-as-usual approaches prevail. Indeed, current worst-case models, which assume not only minimum mitigation but maximum continued exploitation of fossil fuels, posit what amounts to runaway greenhouse warming from mid-century onward.

Geoengineering (also called climate engineering) is a drastic yet appealing option to face these threats. ${ }^{26}$ It refers to strategies that try to alter the climate system through direct human intervention, broadly divided into two categories: removing carbon dioxide from the atmosphere and modifying the reflective properties of the atmosphere. Although the science of geoengineering is mentioned in the most recent IPCC assessment report, little mention is made of governance aspects or the global justice and security implications it carries with it. Currently, no international treaties govern 
geoengineering, and no international organisation has offered policy guidance. Still, national scientific bodies have begun to consider its applications and implications, and the Institute for Advanced Sustainability Studies has even suggested a code of conduct.

Carbon-dioxide removal, or carbon sequestration, is the better understood of the two approaches. It aims to remove $\mathrm{CO}_{2}$ from the atmosphere and store it either by trapping it in the oceans through chemical reactions or in natural sinks underground. The most basic sequestration techniques are widely considered safe for experimentation and limited implementation. Modifying the reflective properties of the atmosphere - also called albedo modification or solar-radiation management (SRM) - is the more controversial approach. It seeks to increase the atmosphere's reflective properties by dispersing aerosols, or through cloud-seeding or brightening techniques, for example, to keep a larger fraction of the sun's heat from reaching the lower atmosphere, lowering global temperatures if done on a large enough scale. Unlike storing excess carbon, however, these techniques can fundamentally alter other important climate dynamics, such as regional precipitation patterns, and they do not alter GHG concentrations or their contributions to ocean acidification.

SRM strategies are likely to have unforeseen trans-boundary impacts, would pose a host of governance challenges and ethical concerns, and do not address the root causes of carbon pollution. Any SRM experimentation should, therefore, be undertaken with the greatest caution. In 2011, 160 civil-society organisations and other non-governmental actors lobbied the IPCC not to promote geoengineering, fearing that it would overshadow broader climate-mitigation efforts and divert funds that might otherwise be used for climate adaptation. Indeed, some forms of geoengineering may be a growing risk to orderly climate-change management because they appear temptingly inexpensive, and there is no framework in place to prevent unwise experimentation, even on a fairly large scale.

Climate-engineering experiments should be subject to careful scrutiny, especially those involving solar-radiation or albedo-management techniques. All such experiments should be subject to review and approval by an expert advisory board attached to a new climate-research registry. 
Furthermore, UN member states should agree to treat its decisions as binding, in the common interest; an appeals board would also be desirable. All atmospheric research involving solar-radiation management should be considered human-subject experimentation insofar as its intent is to affect the living conditions of people and, even if conducted over uninhabited places, experimental effects could carry into populated areas. Approval should be conditioned on best available evidence and modelling indicating that expected trans-boundary effects are minimal. Experiments with purposeful trans-boundary impacts, where scientifically warranted, should also require the formal approval of the nations affected. Carbon-sequestration technologies could have a different threshold of action triggering oversight from the proposed advisory board because the effects of smaller experiments could be quite localised. Larger experiments, or those involving direct extraction of $\mathrm{CO}_{2}$ from the atmosphere, should be presented to the advisory board, and a future climate-research registry should have a special track for recording all approved climate-engineering projects.

Climate change is a threat to the human security of hundreds of millions of people and their livelihoods. Drastic solutions such as geoengineering are not only scientific challenges, but also require our most advanced thinking in terms of governance of their justice and security implications on a planetary scale.

A short-lived aerial bombing campaign or a handful of military advisers may contribute to the protection of civilians for a while, but they will not bring about viable and accountable institutions which have the trust of the people and lead them durably out of a cycle of conflict. Financial stability in our hyperconnected global economy may be maintained by a club of powerful countries, but their detachment from the wider global architecture undermines their legitimacy. Global connectivity amplifies, rather than glosses over, inequalities and inequities. Climate change multiplies threats and hardships as countries continue to debate what an equitable response may look like. Some may be tempted to use geoengineering to generate quick, if 
temporary, respite from the immediate effects of atmospheric warming, but such attempts come with the risk of large-scale experiments going awry, or succeeding but ending abruptly, with potentially devastating consequences for justice and security alike.

What all three examples show is the need for effective transnational governance mechanisms and approaches, which take due account of the security and justice implications of the policies and actions of both governments and non-state actors. Pursuing security and justice jointly in global governance is vital to human progress in the twenty-first century.

\section{Notes}

1 The concept of 'just security' serves as the anchor for the report of the Commission on Global Security, Justice \& Governance, co-chaired by former US secretary of state Madeleine Albright and former foreign minister of Nigeria Ibrahim Gambari. See 'Confronting the Crisis of Global Governance', report of the Commission on Global Security, Justice \& Governance, June 2015, https://www.stimson.org/sites/ default/files/file-attachments/ Commission_on_Global_Security_ Justice\%2O_Governance_o.pdf. The term was first used in the online forum 'Just Security', based at the Center for Human Rights and Global Justice at the New York University School of Law. While not defining the term per se, the online forum emphasises the application of the law to security issues by, for instance, vetting security policy through a legal lens. See https:// www.justsecurity.org/about-us.

2 For further analysis of the intricacies of rule-of-law promotion in fragile and conflict-affected situations, see Anja Mihr and Chandra Lekha Sriram, 'Rule of Law, Security and Transitional Justice in Fragile and Conflict-Affected States', background paper for the Commission on Global Security, Justice \& Governance, May 2015, http://www.stimson.org/sites/ default/files/Commission_BP_Mihr_ Sriram.pdf.

3 Thomas Weiss, Tatiana Carayannis and Richard Jolly, "The "Third" United Nations', Global Governance: A Review of Multilateralism and International Organizations, vol. 15, no. 1, 2009, pp. 123-42.

4 Thomas Weiss, D. Conor Seyle and Kelsey Coolidge, 'The Rise of NonState Actors in Global Governance - Opportunities and Limitations', One Earth Future Discussion Paper, 2013, http://oneearthfuture.org/sites/ oneearthfuture.org/files/documents/ publications/GGWEISSFinalR6_o.pdf.

5 Simon Curtis, 'Global Cities and the Transformation of the International System', Review of International Studies, vol. 37, no. 4, October 2011, pp. 1,923-47. 
6 City A.M., 'World Charity Index 2013', 20 December 2013, http://www.cityam. com/sites/default/files/sites/default/ files/content-editors/u3996o/WCI2013. pdf.

7 Liyan Chen, 'The World's Largest Companies: China Takes Over the Top Three Spots', Forbes, 7 May 2014, http://www.forbes. com/sites/liyanchen/2014/05/o7/ the-worlds-largest-companies-chinatakes-over-the-top-three-spots.

8 This is an initiative of the Peruvian Presidency of the 2oth Conference of the Parties (COP2O), the French Presidency of COP21 and the secretarygeneral of the United Nations.

9 Unless otherwise noted, this section draws from Section 4 of 'Confronting the Crisis of Global Governance'.

10 World Bank, 'Fragility, Conflict and Violence: Overview', September 2015, http://www.worldbank.org/en/topic/ fragilityconflictviolence/overview.

11 Stimson Center Future of Peace Operations Program, 'Uniformed Personnel in Peace Operations, 1948-2014', unpublished spreadsheet. Copy available from the authors upon request.

12 Ibid.; and William J. Durch, 'Police in UN Peace Operations: Evolving Roles and Requirements', Challenges Forum Occasional Papers, No. 4, August 2014, available at http:// www.challengesforum.org/en/ Reports--Publications/?r=2.

13 Derived from 'Confronting the Crisis of Global Governance', pp. 32-8.

14 Wendy Lambourne, 'Transitional Justice and Peacebuilding After Mass Violence', International Journal of Transitional Justice, vol. 3, no. 1, 2009, pp. $28-48$. 'Further Action Needed to Reinforce Signs of Market Recovery: IMF', IMF Survey, 21 April 2009, https://www. imf.org/external/pubs/ft/survey/ so/2009/RESo42109C.htm.

16 United Nations, 'Report of the Commission of Experts of the President of the United Nations General Assembly on Reform of the International Monetary and Financial System', 2009, p. 12. The Commission was chaired by Professor Joseph E. Stiglitz.

17 For an authoritative account, see Kaarlo Tuori and Klaus Tuori, Eurozone Crisis: A Constitutional Analysis (Cambridge: Cambridge University Press, 2014). See also Thomas Piketty, Capital in the TwentyFirst Century (Cambridge, MA: Harvard University Press, 2013).

18 International Labour Organisation (ILO), ‘World of Work Report 2014: Developing with Jobs', 2014, p. 2, http:// www.ilo.org/wcmsp5/groups/public/--dgreports/---dcomm/documents/ publication/wcms_243961.pdf.

19 Ibid., p. 2.

20 Global Migration Group and ILO, 'Fact-Sheet on the Impact of the Economic Crisis on Immigration Policies', May 2010, http://www. globalmigrationgroup.org/sites/ default/files/uploads/documents/ILO_ FactSheet_1_final_rev_May_2010.pdf; and ILO, 'Global Employment Trends 2014', p. 21, http://www.ilo.org/ wcmsp5/groups/public/---dgreports/--dcomm/---publ/documents/ publication/wcms_233953.pdf.

21 'Parting of the Ways', The Economist, 20 November 2014, p. 22. 
22 The new framework for global economic cooperation should adopt the post-2015 Sustainable Development Goals framework, meaning that civilsociety engagement would occur via the major groups. Not only large international civil-society organisations and business groups, but youth, women, trade unions, local authorities, farmers and the scientific community are all treated as separate major groups.

23 Climate Change 2013: The Physical Science Basis, Working Group
I Contribution to the IPCC $5^{\text {th }}$

Assessment Report, 'Summary for

Policymakers'.

24 Will Steffen et al., 'Planetary

Boundaries: Guiding Human

Development on a Changing Planet',

Science, vol. 347, no. 6,223, 2015, p. 791.

25 Climate Change 2013: The Physical

Science Basis, pp. 4-5.

26 See, for example, Jeffrey Mazo,

'Geoengineering: Don't Just Do

Something, Stand There', Survival, vol.

57, no. 3, June-July 2015, pp. 185-192. 
112 | William Durch, Joris Larik and Richard Ponzio 